\title{
The Effectiveness of Think-Talk-Write (TTW) Learning Strategy in the Critical Thinking and Mathematical Communication
}

\author{
M. Farid Nasrulloh ${ }^{1 *}$ Fitri Umardiyah ${ }^{2}$ \\ ${ }^{1}$ Departement of Mathematics Education, Faculty of Education Science, Universitas KH. A. Wahab Hasbullah, \\ Indonesia \\ ${ }^{2}$ Departement of Mathematics Education, Faculty of Education Science, Universitas KH. A. Wahab Hasbullah, \\ Indonesia \\ *Corresponding author. Email: faridnasrulloh@unwaha.ac.id
}

\begin{abstract}
The purpose of this study is to describe the effectiveness of learning mathematics using the Think-Talk-Write (TTW) strategy and conventional learning approaches in terms of critical thinking and mathematical communication, comparing the effectiveness of Think-Talk-Write (TTW) strategy and conventional learning approaches in terms of thinking. critical and mathematical communication. The research methods is a quasi-experimental, the population in this study was students of class X MA Bahrul Ulum Jombang, totaling three classes. Based on the sampling, it was obtained that class X-IIS-1 as the experimental class and class X-IIS-II as the control class. The data was analyzed using the one-sample ttest, MANOVA test with T2 Hotteling and t test with Bonferroni Criteria. The results of research showed that at the $95 \%$ level of significansy, (1) The application of the Think-Talk-Write (TTW) learning strategy is effective, while the application of conventional learning is not effective in terms of critical thinking skills and mathematical communication. (2) The application of the Think-Talk-Write (TTW) learning strategy is more effective than the application of conventional learning in terms of critical thinking skills and mathematical communication.
\end{abstract}

\section{Keywords: Think-Talk-Write (TTW) learning strategy, the mathematical communication}

\section{INTRODUCTION}

One of the subjects were taught at every level of education in Indonesia from Elementary School (SD) to Senior High School (SMA) is mathematics. Mathematics is one of the lessons that is the basis for other sciences because it includes the ability to count, logic and think. Regulation of the Minister of National Education of the Republic of Indonesia Number 22 of 2006 explains that the objectives of learning mathematics in schools include students having the ability to understand mathematical concepts, explain the relationship between concepts, use reasoning, solve problems, and communicate ideas.

According to [1], Indonesia's participation in the International Trends in International Mathematics and Science Study (TIMSS) study and the Program for International Student Assessment (PISA) since 1999 shows that the achievements of Indonesian children have been less encouraging in several reports. issued by TIMSS and PISA. The average math ability (PISA 2013 result) stands at 375 points, still quite low compared to the OECD average of 494 points. Meanwhile, the average scientific literacy of students in Indonesia is still low, namely 382 points compared to OECD countries, which is 501 points. Accessing students thinking when students solve problems is essensial to get information potensial and also difficulties [2].

People who think critically will tend to be positive about mathematics. They will try to reason and find problem solving strategies. In order to build mathematical communication skills in mathematics learning, students need to be faced with problems so that they construct their thoughts to find solutions. Mathematical communication is needed so that students can solve mathematical problems. Not developing mathematical communication will hinder students in solving math problems.

The goal of learning mathematics has not been fully achieved in several schools, based on observations made by researchers at MA Bahrul Ulum Jombang that the learning achievements achieved by class $\mathrm{X}$ students in the 2018/2019 academic year on the results of even semester final assessment (PAS) have not reached the 
completeness standard individual of 75 , this condition shows that most students do not master the given material. There are several factors that affect the achievement of student learning completeness standards, including: Students are less active during learning because learning is still dominated by teachers, students are less confident in working on questions given by the teacher and students waiting for teacher assistance to work on the questions given.

Critical thinking is a mental activity that cannot be separated from human life. The critical thinking ability of each individual is different from one another so that it needs to be nurtured from an early age. Thinking occurs in every human mental activity that functions to formulate or solve problems, make decisions and find reasons. According to [3], the critical thinking skills of students can be raised through a learning process that involves them actively. So that teachers must be able to implement learning that can directly involve the active role of students in constructing their knowledge.

According to [4], thinking is manipulating or managing and transforming information in memory. Thinking is often done to form concepts, reason and think critically, make decisions, think creatively, and solve problems. According to [5], critical thinking is the most influential trend in education in terms of how teachers teach and how students learn. based on this statement, it is the teacher's duty to develop critical thinking in learning to hone both the teacher's ability to teach and how students learn.

Learning mathematics really requires a variety of learning strategies. By using a variety of learning strategies, a teacher will be able to improve the quality of student learning outcomes. One of the learning strategies that is expected to improve mathematical communication is the Think-Talk-Write (TTW) Strategy. TTW is a learning strategy that aims to improve and develop the creativity of students in communicating actively through group discussions and presentations. According to [6], TTW can improve students' mathematical representation and communication skills.

Communication is a way to solve and clarity a problem through understanding [7]. Communication is the process of conveying messages by someone to another. This message can be conveyed through words, writing, or deeds. Sardiman in [8] states that communication is telling news, knowledge, thoughts and values with the aim of inspiring participation so that things that are announced become common property. Communication for teachers is the delivery of messages in the form of concepts, methods, or ways of solving problems in everyday life or problems related to a particular theory so that the message conveyed can be understood by students. Isoda in [9] presents several components of mathematical communication, namely:
- Use appropriate language to promote conceptual understanding and discourse.

- Emphasizes logical reasoning.

- Distinguish between conceptual explanations and procedural descriptions

- Make meaningful representations.

- Cultivate sympathy

The importance of mathematical communication is contained in the mathematics learning objectives listed in the competency standards of mathematics subjects, namely developing the ability to convey information or communicate ideas, among others through oral speech, graphics, maps, diagrams and explaining ideas. The Principles and Standards [10] also highlight the importance of communication as an essential part of mathematics and mathematics education. Through communication, an idea becomes the object of reflection for improvement, discussion and change, and it is this process that helps to make meaningful and define ideas and make the idea more common.

One of the lessons that have been of concern and recommended by education experts to use is cooperative learning. Slavin in [11] argues that several research results prove that the use of cooperative learning can improve learning achievement as well as improve social relationship skills, foster an attitude of accepting self-deprivation and other people. In additional to learning model and approach, another factor may also affect the mathematics learning outcomes [12]. One of the cooperative learning that is expected to improve learning outcomes is the ThinkTalk-Write (TTW) strategy. According [13] say that the TTW flow begins with the involvement of students to think for themselves after the reading process, then talk or share with friends before writing, after which the results of the discussion are expressed in writing.

According to Zainal in [14] that TTW is a cooperative learning that aims to improve and develop students' creativity in critical thinking, mathematical communication, work through group discussions and presentations. Think-Talk-Write (TTW) has at least four steps, namely:

- Thinking, students are given the opportunity to think about material or answer questions posed by the teacher in the form of worksheets and work on individually.

- Talking (Talking), students are organized in groups. Students are directed to be actively involved in group discussions to complete or answer the given worksheets. Students are expected to be able to share answers and opinions with their respective group members.

- Write, students are asked to write in their own language and thoughts as a result of the learning and group discussions they get. 
- The results of group discussions are presented in front of the class as well as providing the opportunity for other groups to correct their work.

The advantages of the Think-Talk-Write (TTW) strategy in mathematics learning according to Ansari [14] include: 1) accelerating proficiency in using problem-solving strategies, 2) helping students to accelerate understanding of material and questions, 3) giving students the opportunity to implement a strategy solution to problem. Based on the literature review that has been described, the TTW strategy is expected to improve students' critical thinking skills and mathematical communication.

Based on the background of the problem above, this study focused on the Effectiveness of the TTW Strategy on Critical Thinking and Mathematical Communication of Class X Students of MA Bahrul Ulum Jombang. This study aims to describe: (1) Determine the effectiveness of the TTW strategy on critical thinking and mathematical communication. (2) Knowing the Comparison of the Effectiveness of the TTW Strategy and Conventional Learning on Students' Critical Thinking and Mathematical Communication.

\section{METHODS}

The research methods is a quasi-experimental research (quasi experiment). The quasi-experiment was chosen because the researcher did not create new classes but used classes as they are in MA Bahrul Ulum Jombang. This study uses the independent variable, namely the Think-Talk-Write (TTW) learning strategy, while the dependent variable is the critical thinking ability and mathematical communication. The research design used was quasi-experiments with the nonequivalent (pre-test and post-test) group design.

The population of the study were all students of class X MA Bahrul Ulum Jombang in the even semester of the 2019/2020 school year. Sampling was done by using a random technique (random) from existing classes. The first class is taught mathematics using the Think-Talk-Write (TTW) learning strategy, while the second class uses the conventional method.

The research instrument used in this study was a test. The test in this study consisted of pretest and posttest questions in the form of description questions which were used to analyze students' critical thinking skills and mathematical abilities. Before the test questions are used, first the test questions are tried out on students, so the researcher needs to see how the test questions were made. Good test questions are valid and reliable test questions, so the researcher needs to test the validity and reliability.

The steps to be carried out in data analysis are as follows: (1) descriptive analysis, (2) assumption testing, and (3) hypothesis testing. Descriptive analysis serves to describe the characteristics of the research data and answer descriptive problems. The assumption test that will be carried out is the normality test and homogeneity test. The normality test is used to find out the data taken from each dependent variable comes from a population that is normally distributed or not. The normality test is carried out using the mahalanobis distance formula. The homogeneity test was carried out using the Box's M test with the help of SPSS 21.0 for Windows.

Hypothesis testing uses the one-sample t-test. This test aims to analyze whether the TTW strategy is effective against critical thinking skills and mathematical communication. The next test used the multivariate mean difference test using the $\mathrm{F}$ test with T2 Hotteling's and the Bonferroni t-test to determine the mean difference between the two groups and the difference in the effectiveness of the two studies on each dependent variable.

\section{RESULT AND DISCUSSION}

Data description regarding the data and analysis obtained during the study. The data collected is divided into two, namely data before treatment and after treatment. The data before the treatment contained the pretest data for critical thinking and students' mathematical communication, while the data after the treatment contained the posttest data for critical thinking and mathematical communication which was carried out in both classes. The experimental class applies mathematics learning using the Think-TalkWrite (TTW) learning strategy in class X IIS-1 students and the control class uses conventional mathematics learning in class X IIS-2 MA Bahrul Ulum Jombang.

At the first meeting, the researcher and the teacher conveyed the learning objectives using the Think-TalkWrite (TTW) learning strategy in class X IIS-I, which amounted to 32 students. Students are very enthusiastic about listening to what the teacher says, considering that this learning strategy is new to them. The researcher also conveyed his apperception in the form of RPP and worksheets that had been prepared. After that, the researcher and the teacher gave a pretest in the form of questions to students. The obstacles that occurred at the first meeting were as follows: (1) there were some students who did not concentrate on paying attention to learning and thought that mathematics, especially Trigonometry, was a difficult material; (2) there are some students who are not enthusiastic about asking their peers, so that group work becomes slow in completing group assignments; (3) students lack confidence to convey the results of their work to other friends.

Noting some of the findings during the learning process of the first meeting, the researcher and the mathematics subject teacher held discussions for improvement during the second meeting learning 
process as follows: (1) the researcher and the teacher gave emphasis in the form of individual special guidance to students who did not understand the material; (2) researchers and teachers provide motivation and enthusiasm for learning so that students can communicate actively with their peers; (3) the researcher and the teacher motivate students to dare to express their opinions, if there is an inaccurate student explanation, the researcher and teacher provide guidance as needed to complete the student's explanation. With the improvement based on the evaluation and input from the mathematics subject teacher, the third meeting and the following proceeded according to the learning plan that had been prepared. During learning, students are more enthusiastic and enthusiastic about taking part in learning. Students are also enthusiastic about helping each other and discussing with their friends and have the courage to express their opinions both to one group of friends and to another group. By utilizing peer tutors, students who have high abilities can help friends who do not understand and make them more motivated in learning.

At the talk stage, group discussions are divided heterogeneously so that all students can mingle and be able to work together in completing group assignments. Through this group discussion students help each other, remind each other in a team of each group. So that the assignment given by the teacher can be completed properly. Students are also seen actively communicating among groups to complete assignments and then they write down the results individually. The results of the group work are then presented to the other groups. Through this presentation, students can convey the results of their thoughts (think) through oral and written. So that it can increase students' confidence and enthusiasm for learning mathematics.

The learning implementation in the control group was carried out in class X IIS-2 with a total of 30 students. The results of the researchers' observations were that there were no obstacles during the implementation of learning, because students were used to conventional learning approaches. The first time the teacher delivered the lesson plan along with the prepared appercies. Some of the researchers' findings when observing the learning process in the control class are as follows: (1) students listen to and follow the learning given by the teacher carefully; (2) students do the questions according to the teacher's orders, but the students' answers are similar to the examples given by the teacher; (3) when teachers give students the opportunity to ask questions, students are less active in responding; (4) when given the opportunity to present answers, students are less active so that the teacher explains it again in a classical way.

At the time of conventional learning with the lecture method students seemed less active, because they tended to listen to explanations from the teacher and work on questions based on the examples that had been given. If students are given a question of a different type, they will find it difficult to complete the answer. Students also rarely communicate the answer ideas either with the teacher or with their peers. This condition makes students lack skills in developing critical thinking skills [15] and mathematical communication.

Based on the results of student research before and after treatment of the two class groups show that the experimental group students obtained a significant increase in the average value, from the pretest results obtained an average score of 28.69 critical thinking results and 28.1 mathematical communication so that the total average score was 56. 8. Whereas for the posttest, the average score of critical thinking was 40.1 and mathematical communication was 42.5 , so that the average number was 82.7 or an increase of 25.9. The data above also shows that the control group students get an average pretest result, get an average score of 24.1 critical thinking results and 27.9 mathematical communication, so the total average score is 52. As for the posttest, the average score -The mean value of critical thinking is 34.13 and mathematical communication is 37.3 so that the average number is 71.4 or an increase of 19.4. Thus it can be said that the application of learning with the TTW strategy is effective in terms of students' critical thinking skills and mathematical communication.

The results of hypothesis testing using the univariate one-sample t-test at the $95 \%$ confidence level indicated that the critical thinking ability variable obtained a significance value $=0.000<0.05$, which means that the TTW strategy is effective in terms of critical thinking skills and the mathematical communication ability variable is obtained a value significance $=0.000<0.05$, which means that the TTW strategy is effective in terms of mathematical communication skills. Thus it can be concluded that at the $95 \%$ confidence level, mathematics learning with the TTW strategy is effective in terms of students' critical thinking skills and mathematical communication. This is in line with research conducted by [10] that students 'mathematical communication skills in TTW learning assisted with fun cards are better than the PBL model and student selfconfidence has a positive effect on students' mathematical communication.

The TTW learning strategy begins with the involvement of students to think (Think) or have a dialogue with themselves after the reading process, after which they talk or discuss (Talk) with their friends before writing (Write). Such an atmosphere can work effectively if it is done in heterogeneous groups of 3-5 students. Each group is given a worksheet, then asked to read, take notes, explain, listen and share ideas with friends and who then express it in writing. So the TTW 
strategy encourages students to actively think, speak, and write on the material given.

In addition to the experimental group, the control class group was treated using a conventional approach. The posttest results for critical thinking skills and mathematical communication in the control class showed a slight increase, the average pretest score for critical thinking skills was 24.13 and the post-test average score for critical thinking skills was 27.9 (increased by 3.8). As for the mathematical communication skills, the pretest average score was 34.13 and the posstest result average score was 37.3 (an increase of 3.21). This increase was due to the opportunity for students to ask questions and do more questions, thus causing learning outcomes to be slightly better than learning outcomes before being given treatment.

Based on the results of the pretest and posttest on the ability to think critically and mathematically communicate there is a slight increase, but the results of data analysis carried out by the univariate one-sample ttest at the $95 \%$ confidence level indicate that the aspect of critical thinking skills obtained a significance value $=$ $0.739>0,05$, meaning that the conventional approach is not effective in terms of critical thinking skills and for the aspect of mathematical communication, a significance value of $=0.267>0.05$ is obtained, meaning that the conventional approach is not effective in terms of mathematical communication skills. Thus it can be concluded that the conventional approach is not effective in terms of students' critical thinking skills and mathematical communication.

In addition to the results of descriptive analysis, the results of hypothesis testing using the multivariate test carried out with the T2 Hotteling formula obtained the value of Fcount $=15.926>$ Ftable $=3.15$ with a significance level of $5 \%$. Thus it can be concluded that at the $95 \%$ confidence level there is a difference in effectiveness between the TTW learning strategy and the conventional approach in terms of students' critical thinking and mathematical communication skills. From the Anova results with Bonferroni's criteria for critical thinking skills, the significance value is obtained = $0.038<0.05$, meaning that the TTW learning strategy is more effective than the conventional approach in terms of critical thinking skills, while for mathematical communication skills, the significance value $=0.024<$ 0,05 , meaning that the TTW learning strategy is more effective than the conventional approach in terms of mathematical communication skills.

In this study, it was found that the Think-Talk-Write (TTW) learning strategy was more effective than conventional learning. This effectiveness is because there are several things in the TTW learning strategy, namely: (1) students can be active in learning and express their ideas (think); (2) students have the opportunity to express their opinions to peers (talk); (3) students with high mathematical abilities can share with friends (talk); (4) students have experience to work on problems given in the LKS; (5) with the reinforcement or rewards from the teacher, students will be more enthusiastic and confident in solving math problems.

\section{CONCLUSION}

Based on the discussion above, this research can be concluded as follows. (1) The application of the ThinkTalk-Write (TTW) learning strategy is effective, while the application of conventional learning is not effective in terms of critical thinking skills and mathematical communication. (2) The application of the Think-TalkWrite (TTW) learning strategy is more effective than the application of conventional learning in terms of critical thinking skills and mathematical communication.

\section{ACKNOWLEDGMENT}

The author would like say thanks to Kemenristek/BRIN for providing support this research and also parents who gave encouragement during this research process. The author also expresses his gratitude to all leaders and colleagues at the KH. A. Wahab Hasbullah University for providing support and cooperation during the writing of this article.

\section{REFERENCES}

[1] M. F. Nasrulloh, Penerapan Model Kooperatif Tipe TPSq (Think Pairs Square) untuk Meningkatkan Kreativitas dan Prestasi Belajar Matematika Siswa Sekolah Dasar, EDUSCOPE, vol. 5, no. 01, hlm. 12-23, 2019.

[2] M. Sapti et al., Comparing Model-Building Process: A Model Prospective Teachers Used in Interpreting Students' Mathematical Thinking, Journal on Mathematics Education, vol. 10, no. 2, 2019, doi: 10.22342/jme.10.2.7351.171-184.

[3] M. I. Chrissanti dan D. B. Widjajanti, Keefektifan Pendekatan Metakognitif Ditinjau dari Prestasi Belajar, Kemampuan Berpikir Kritis, dan Minat Belajar Matematika, JRPM, vol. 2, no. 1, hlm. 51-62, 2015, doi: 10.21831/jrpm.v2i1.7150.

[4] J. W. Santrock, Perkembangan Anak Edisi 7 Jilid 2, 7 ed. Jakarta: Erlangga, 2011.

[5] N. F. Amalia dan E. Pujiastuti, Kemampuan Berpikir Kritis dan Rasa Ingin Tahu Melalui MoDEL PBL, 1, hlm. 523-531, 2017.

[6] B. Gunur, D. A. Lanur, dan P. Raga, Hubungan kemampuan Numerik dan Kemampuan Spasial Terhadap Kemampuan Komunikasi Matematis Siswa, Pythagoras: Jurnal Pendidikan 
Matematika, vol. 14, no. 2, Art. no. 2, 2019, doi: 10.21831/pg.v14i2.27250.

[7] S. Setiyani, D. P. Putri, F. Ferdianto, dan S. H. Fauji, Designing A Digital Teaching Module Based on Mathematical Communication in Relation and Function," Journal on Mathematics Education, vol. 11, no. 2, Art. no. 2, 2020, doi: 10.22342/jme.11.2.7320.223-236.

[8] S. Khoiriyah, Kemampuan Komunikasi Matematis Mahasiswa dalam Pemecagan Masalah Kalkulus II, Jurnal e-DuMath, vol. 2, no. 2, hlm. 202-209, 2016.

[9] S. A. Ulep, Developing Mathematical Communication in Philippine Classrooms, in: Proceedings of APECTSUKUBA International Conference III, Innovation of Classroom Teaching and Learning through Lesson Study, Focusing on Mathematical Communication, pp. 1-10, 2007.

[10] NCTM, Principles and Standards for School Mathematics, Restorn: NCTM, 2000.

[11] W. Sanjaya, Strategi Pembelajaran.,Jakarta: Prenada Media, 2008.
[12] S. M. Ardiyani, G. Gunarhadi, and R. Riyadi, Realistic Mathematics Education In Cooperative Learning Viewed From Learning Activity, Journal on Mathematics Education, vol. 9, no. 2, 2018, doi: 10.22342/jme.9.2.5392.301-310.

[13] S. Jami'atun dan K. Wijayanti, Kemampuan Penalaran Matematis pada Pembelajaran TTW (Think Talk Write) Ditinjau dari Gaya Belajar Siswa, PRISMA, Prosiding Seminar Nasional Matematika, vol. 3, hlm. 599-604, 2020.

[14] M. Simanjuntak, Upaya Meningkatkan Hasil Belajar Siswa pada Sub Pokok Bahaan Penjumlahan dan Pengurangan Bilangan Bulat dengan Think-Talk-Write (TTW) Berbantuan Garis Bilangan 2011/2012, UNIMED, 2012.

[15] D. S. N. Afifah and R. L. Ningrum, Critical Thinking of Field Dependent Student's in Problem Solving, International Journal on Teaching and Learning Mathematics, vol. 1, no. 1, pp. 31-38, 2018. 